DOI: $10.1515 /$ sgem-2017-0019

\title{
ENGINEERING AND ECONOMIC PRECONDITIONING FOR DRAINING OF THE PWiK FACILITIES IN GŁOGÓW
}

\author{
URSZULA KOŁODZIEJCZYK \\ University of Zielona Góra, Faculty of Civil and Environmental Engineering, \\ ul. prof. Z. Szafrana 15, 65-516 Zielona Góra, \\ e-mail: U.Kolodziejczyk@iis.uz.zgora.pl
}

\begin{abstract}
The facilities belonging to Przedsiębiorstwo Wodociągów i Kanalizacji (PWiK) in Głogów have been erected on the floodplain of the Odra river. In consequence, they are in a state of permanent dampness or flooded. Therefore, the need has arisen for indicating an effective method of draining the facilities. In the paper, four different methods of solving the problem have been indicated which are differentiated in both engineering and economic respects.
\end{abstract}

\section{DESCRIPTION OF THE STUDY AREA}

The facilities belonging to PWiK (Sewage and Water Utility) in Głogów are situated at 52, Łąkowa St. (Fig. 1). The area is a fragment of the Baruth-Głogów Marginal Stream Valley and of a secondary morphological unit, i.e. the Milicz-Głogów Downland. The bed of the Odra river is characterised here by a significant sinuosity (the sinuosity index is in the range from 1.45 to 1.53 ) and a multi-bed system (the Old Odra river flows at a distance of ca. $100 \mathrm{~m}$ to the north of PWiK facilities and, at the same time, ca. $500 \mathrm{~m}$ from the main bed of the Odra). The complex of PWiK facilities in Głogów is protected against flooding by a system of flood embankments [1-4]. In spite of this, the facilities are frequently permeated and sometimes - simply flooded (Fig. 2).

The identification of the geological structure as made for the drainage analysis, indicated that in the surface zone, to a depth of $1.8-4.1 \mathrm{~m}$ b.t.l., there is a nonconstructional bank or humus (Fig. 3), and below it - medium- and coarse-grained sands, or, locally - sandy clays not drilled to the depth of $5.0 \mathrm{~m}$ b.t.l. (up to the ordinates of $70,30 \mathrm{~m}$ a.s.1.). Underground waters of the first water-bearing level occur relatively shallowly - at a depth of 0.9 to $3.8 \mathrm{~m}$ b.t.l. (72-73 $\mathrm{m}$ a.s.1.). They exhibit a free water table dependent upon the terrain ordinate as well as the water level in the Old Odra and the Odra. The waters occur in two water-bearing layers: the shallower (Holocene) layer, occurring in river deposits, and a deeper (Pleistocene) one developed in water-glacial sands occurring amongst glacial bolder-clays [4]. Both the water-bearing layers have a distinct and steady hydraulic contact resulting from an erosive slit of boulder-clays. Therefore, in spite of the fact that the deeper layer table is slightly perched, it usually stabilises at the same level as the free table of the upper layer. 


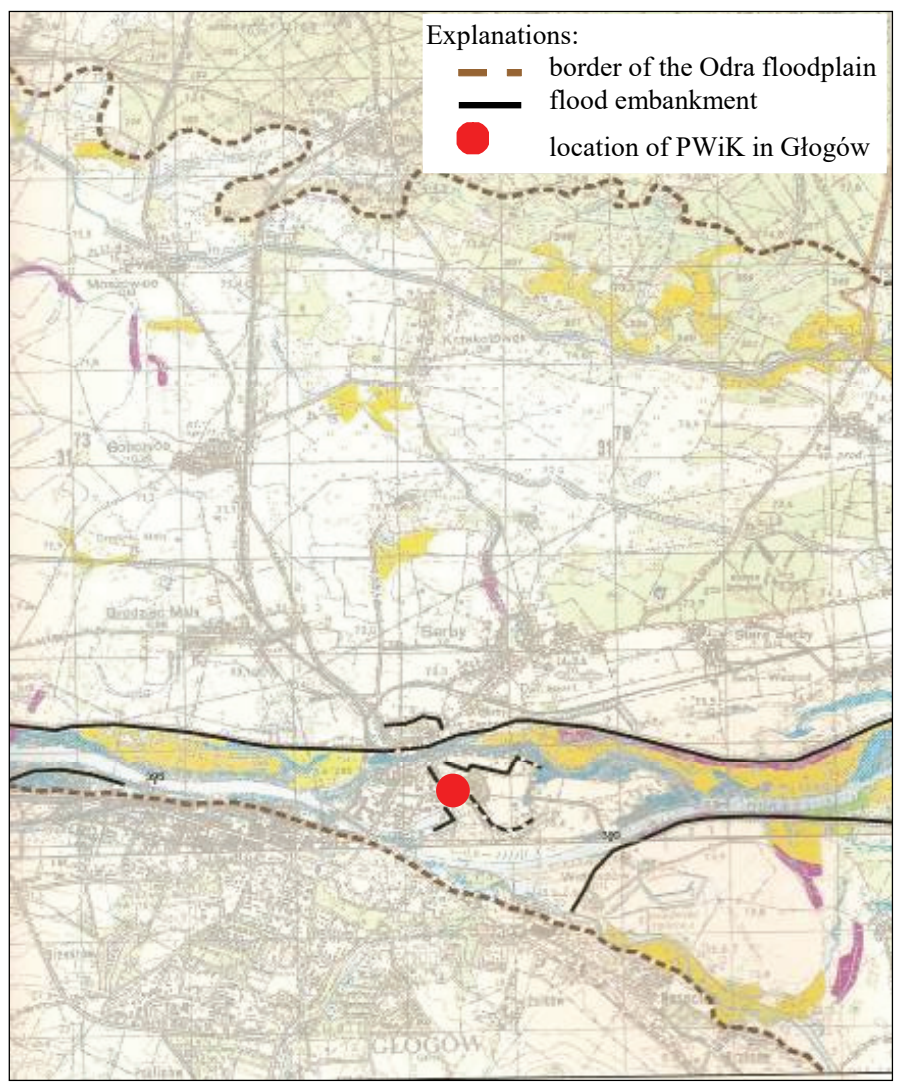

Fig. 1. The location of the PWiK Głogów facilities in relation to the Odra floodplains (scale 1:30000)

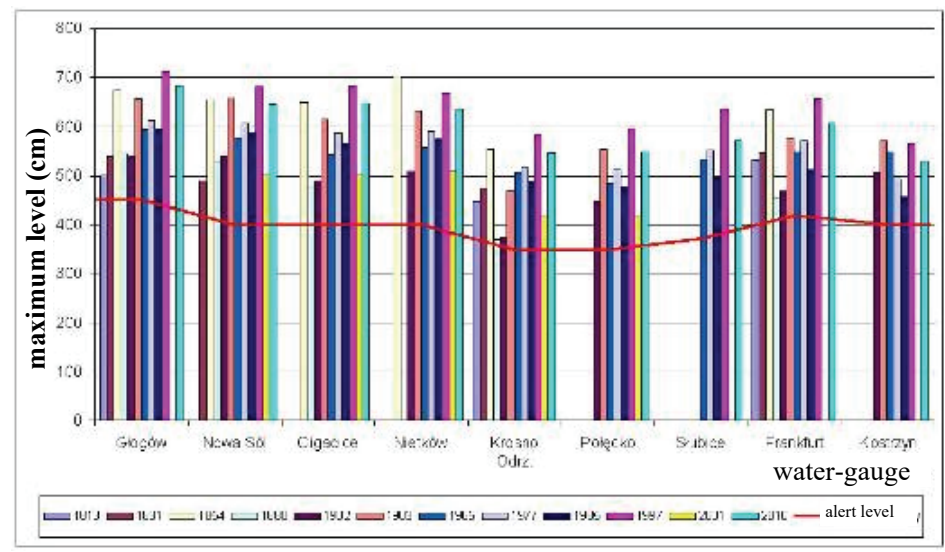

Fig. 2. Large inundations recorded in the Middle Odra river basin 


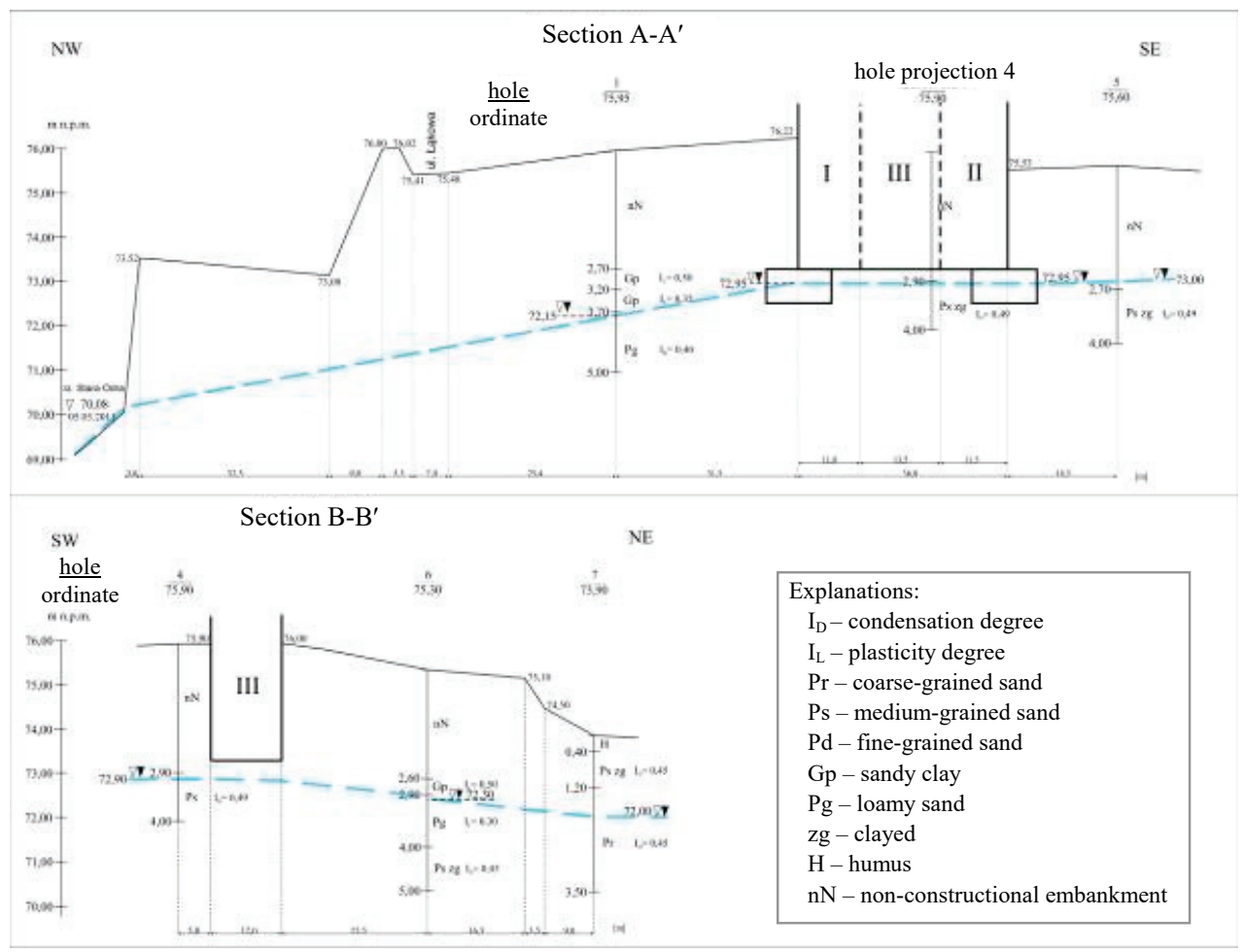

Fig. 3. Geological and engineering cross sections (the section location is shown in Figs. 4-6)

\section{METHODOLOGY OF THE CALCULATION OF WATER FILTRATION TO CELLARS OF THE PWIK FACILITIES IN GŁOGÓW}

The following data have been assumed for the filtration volume calculation:

- computational water table (as of 5 March 2011) - 72.95 m a.s.l.,

- predicted water table at the alert level $-74.73 \mathrm{~m}$ a.s.1.,

- direct width of the building section field $-49.0 \mathrm{~m}$,

- active width of the building section field $-70.0 \mathrm{~m}$,

- ground (embankment) filtration coefficient $-0.5 \cdot 10^{-3} \mathrm{~m} / \mathrm{s}$,

- thickness of the water layer above the floor level in the alert condition $-1.5 \mathrm{~m}$,

- pressure line drop $-1.5 \%$

- floor (averaging) ordinate $-73.20 \mathrm{~m}$ a.s.1.,

- lowered water table level $-72.20 \mathrm{~m}$ a.s.l.

The theoretical volume of water inflowing to the computational section from the inflow side was calculated by the following formula: 


$$
\begin{gathered}
Q=k \cdot i \cdot F=0.5 \cdot 10^{-3} \cdot 0.015 \cdot(70 \cdot 1.5) \\
=0.000788 \mathrm{~m}^{3} / \mathrm{s}=2.84 \mathrm{~m}^{3} / \mathrm{h}=68 \mathrm{~m}^{3} / \mathrm{d} .
\end{gathered}
$$

\section{ASSESSMENT OF THE FEASIBILITY OF DRAINING THE CELLARS OF THE PWIK FACILITIES IN GŁOGÓW}

\subsection{DRAINING BY MEANS OF A NON-DEEPENED DRAINAGE - VARIANT I}

The hydrological calculations for the draining by means of a non-deepened drainage - variant I (Fig. 4) were calculated for a situation similar to the occurrence of the alert condition, while applying the following scheme:

- discharge of non-deepened drainage in the free water table layer

$$
Q=\frac{\pi \cdot k(2 \cdot H-s) \cdot s}{\ln \frac{r}{r_{0}}+\xi_{d}} ; \mathrm{m}^{3} / \mathrm{d}
$$

where:

$\xi_{d}$-hydraulic resistance coefficient for incomplete drainage,

$$
\xi_{d}=\frac{m}{\pi \cdot r_{0}} \ln \frac{8 \cdot r_{0}}{r}-\ln \left(1+\frac{m}{r_{0}}\right),
$$

$r_{0}-$ effective radius

$$
r_{0}=\mu \frac{a_{1}+b_{1}}{4}=40.71 \mathrm{~m},
$$

- drainage action range radius

$$
R \cdot \sqrt{\lg R-\lg r_{0}-0.217}=0.66 \cdot \sqrt{\frac{k}{w} s(2 \cdot H-s)-0.5 r_{0}^{2}}
$$

where: with a method of successive approximations $R=429 \mathrm{~m}$,

- discharge of non-deepened drainage in the free water table layer

$$
Q=1288.4 \mathrm{~m}^{3} / \mathrm{d},
$$

- convection of the water table in the middle of the drainage system

$$
F\left(\frac{r_{0}}{m}\right)=-0.09 \text {, }
$$




$$
\begin{gathered}
\varphi_{1}\left(\frac{r_{0}}{m}\right)=2.9, \\
\varphi_{2}\left(\frac{R}{m}\right)=1.1, \\
\varphi=\varphi_{1}-\varphi_{2}=1.8, \\
h_{a}=s \cdot\left[\frac{\ln \frac{8 \cdot r_{0}}{r}-\pi+2 \cdot \frac{r_{0}}{m} \cdot F\left(\frac{r_{0}}{m}\right)}{\ln \frac{8 \cdot r_{0}}{r}+2 \cdot \frac{r_{0}}{m} \cdot \varphi\left(\frac{r_{0}}{m} ; \frac{R}{m}\right)}\right]=0.15 \mathrm{~m},
\end{gathered}
$$

- verification of the water absorbability of drainage pipelines

$$
\begin{gathered}
q_{\max }=4.85 \mathrm{~m}^{3} / \mathrm{d}, \\
q_{0}=496.4 \mathrm{~m}^{3} / \mathrm{d}, \\
q_{\max }<q_{0},
\end{gathered}
$$

- the condition is met.

In May 2011 (flood), the draining operating conditions were as follows:

- drainage action range radius

$$
R \cdot \sqrt{\lg R-\lg r_{0}-0.217}=0.66 \cdot \sqrt{\frac{k}{w} s(2 \cdot H-s)-0.5 r_{0}^{2}}
$$

which gave the following result calculated with the method of successive approximations $R=365 \mathrm{~m}$,

- discharge of the non-deepened drainage in the free water table layer

$$
Q=896.9 \mathrm{~m}^{3} / \mathrm{d},
$$

- convection of the water table in the middle of the drainage system:

$$
\begin{gathered}
F\left(\frac{r_{0}}{m}\right)=-0.11, \\
\varphi_{1}\left(\frac{r_{0}}{m}\right)=3.1, \\
\varphi_{2}\left(\frac{R}{m}\right)=1.1
\end{gathered}
$$




$$
\begin{gathered}
\varphi=\varphi_{1}-\varphi_{2}=2.0 \\
h_{a}=s \cdot\left[\frac{\ln \frac{8 \cdot r_{0}}{r}-\pi+2 \cdot \frac{r_{0}}{m} \cdot F\left(\frac{r_{0}}{m}\right)}{\ln \frac{8 \cdot r_{0}}{r}+2 \cdot \frac{r_{0}}{m} \cdot \varphi\left(\frac{r_{0}}{m} ; \frac{R}{m}\right)}\right]=0.11 \mathrm{~m},
\end{gathered}
$$

- verification of the water absorbability of drainage pipelines

$$
\begin{gathered}
q_{\max }=3.37 \mathrm{~m}^{3} / \mathrm{d}, \\
q_{0}=456.0 \mathrm{~m}^{3} / \mathrm{d}, \\
q_{\max }<q_{0},
\end{gathered}
$$

- the condition is met.

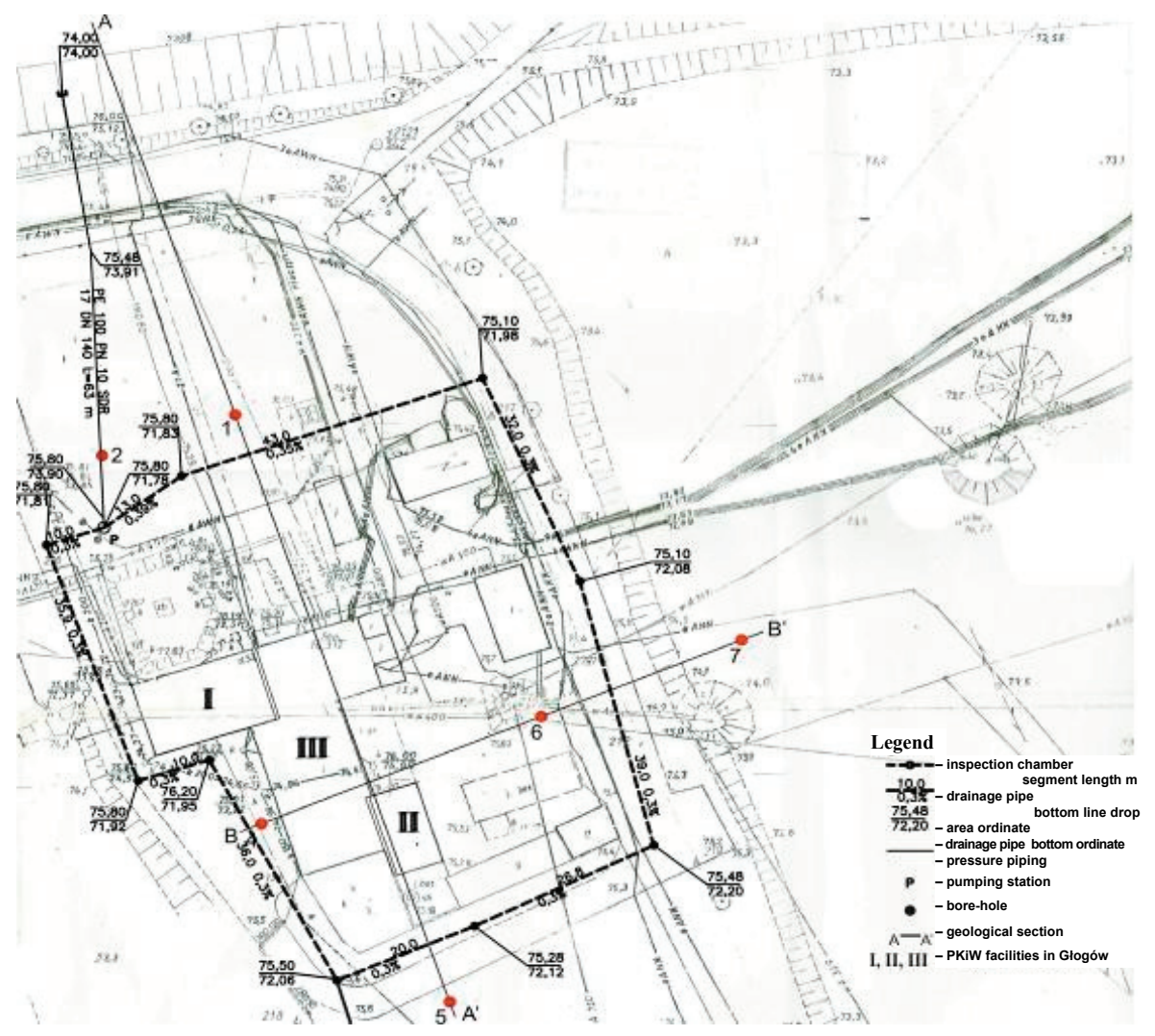

Fig. 4. Draining by means of a non-deepened drainage - variant I 
The drainage in variant I was designed with the use of PVC 160/145 corrugated pipes, with holes $2.5 \times 5.0 \mathrm{~mm}$, with a total length of $265.7 \mathrm{~m}$ and hollows $3.02-4.25 \mathrm{~m}$ and with a drain gradient maintained in the range of $0.30-039 \%$. A filter of granular materials (grain diameter $d=>3 \mathrm{~mm}$ ) was provided for in the form of a single layer surround with a minimum thickness of $150 \mathrm{~mm}$. Observation wells (of a corrugated pipe $315 \mathrm{~mm}$ ) were designed at the points of change of the route direction, and the well bottom was lowered by $0.4 \mathrm{~m}$ from the drainage pipe bottom. It was decided that the function of the collecting well would be performed by the operating chamber of the drainage water pumping station with the following parameters: width $1.5 \mathrm{~m}$, height $5.40 \mathrm{~m}$, operating height $0.66 \mathrm{~m}$, retention volume $1.16 \mathrm{~m}^{3}$, filling time $1.3 \mathrm{~min}$ at the alert level and $1.86 \mathrm{~min}$ at the flood water level (as observed in May 2011). The chamber will be equipped with two pumps with the installed power of $2.2 \mathrm{~kW}$.

The installation cost for variant I for draining the PWiK facilities in Głogów will amount to ca. PLN 3.0 million.

\subsection{DRAINING BY MEANS OF A NON-DEEPENED DRAINAGE - VARIANT II}

The hydrological calculations for draining by means of a non-deepened drainage - variant II (Fig. 5) differing from variant I with the scope of the work - were calculated for a situation similar to the occurrence of the alert condition. The following results were obtained:

- effective radius $r_{0}$

$$
r_{0}=\mu \frac{a_{1}+b_{1}}{4}=32.30 \mathrm{~m},
$$

- drainage action range radius

$$
R \cdot \sqrt{\lg R-\lg r_{0}-0.217}=0.66 \cdot \sqrt{\frac{k}{w} s(2 \cdot H-s)-0.5 r_{0}^{2}},
$$

with a method of successive approximations $R=410 \mathrm{~m}$,

- discharge of the non-deepened drainage in the free water table layer

$$
Q=1185.4 \mathrm{~m}^{3} / \mathrm{d},
$$

- convection of the water table in the middle of the drainage system

$$
\begin{aligned}
& F\left(\frac{r_{0}}{m}\right)=-0.1, \\
& \varphi_{1}\left(\frac{r_{0}}{m}\right)=3.0,
\end{aligned}
$$




$$
\begin{gathered}
\varphi_{2}\left(\frac{R}{m}\right)=1.1, \\
\varphi=\varphi_{1}-\varphi_{2}=1.9, \\
h_{a}=s \cdot\left[\frac{\ln \frac{8 \cdot r_{0}}{r}-\pi+2 \cdot \frac{r_{0}}{m} \cdot F\left(\frac{r_{0}}{m}\right)}{\ln \frac{8 \cdot r_{0}}{r}+2 \cdot \frac{r_{0}}{m} \cdot \varphi\left(\frac{r_{0}}{m} ; \frac{R}{m}\right)}\right]=0.18 \mathrm{~m},
\end{gathered}
$$

- verification of the water absorbability of drainage pipelines

$$
\begin{gathered}
q_{\max }=4.46 \mathrm{~m}^{3} / \mathrm{d}, \\
q_{0}=494.6 \mathrm{~m}^{3} / \mathrm{d} \\
q_{\max }<q_{0}
\end{gathered}
$$

- the condition is met.

In the event of occurrence of conditions similar to those observed in May 2011, the drainage conditions will be as follows:

- drainage action range radius

$$
\begin{gathered}
R \cdot \sqrt{\lg R-\lg r_{0}-0.217}=0.66 \cdot \sqrt{\frac{k}{w} s(2 \cdot H-s)-0.5 r_{0}^{2}}, \\
R=348 \mathrm{~m}, \\
Q=819.7 \mathrm{~m}^{3} / \mathrm{d},
\end{gathered}
$$

- convection of the water table in the middle of the drainage system

$$
\begin{gathered}
F\left(\frac{r_{0}}{m}\right)=-0.15, \\
\varphi_{1}\left(\frac{r_{0}}{m}\right)=3.6, \\
\varphi_{2}\left(\frac{R}{m}\right)=1.1, \\
\varphi=\varphi_{1}-\varphi_{2}=2.5,
\end{gathered}
$$




$$
h_{a}=s \cdot\left[\frac{\ln \frac{8 \cdot r_{0}}{r}-\pi+2 \cdot \frac{r_{0}}{m} \cdot F\left(\frac{r_{0}}{m}\right)}{\ln \frac{8 \cdot r_{0}}{r}+2 \cdot \frac{r_{0}}{m} \cdot \varphi\left(\frac{r_{0}}{m} ; \frac{R}{m}\right)}\right]=0.10 \mathrm{~m},
$$

- verification of the water absorbability of drainage pipelines;

$$
\begin{gathered}
q_{\max }=3.1 \mathrm{~m}^{3} / \mathrm{d}, \\
q_{0}=455.6 \mathrm{~m}^{3} / \mathrm{d}, \\
q_{\max }<q_{0},
\end{gathered}
$$

- the condition is met.

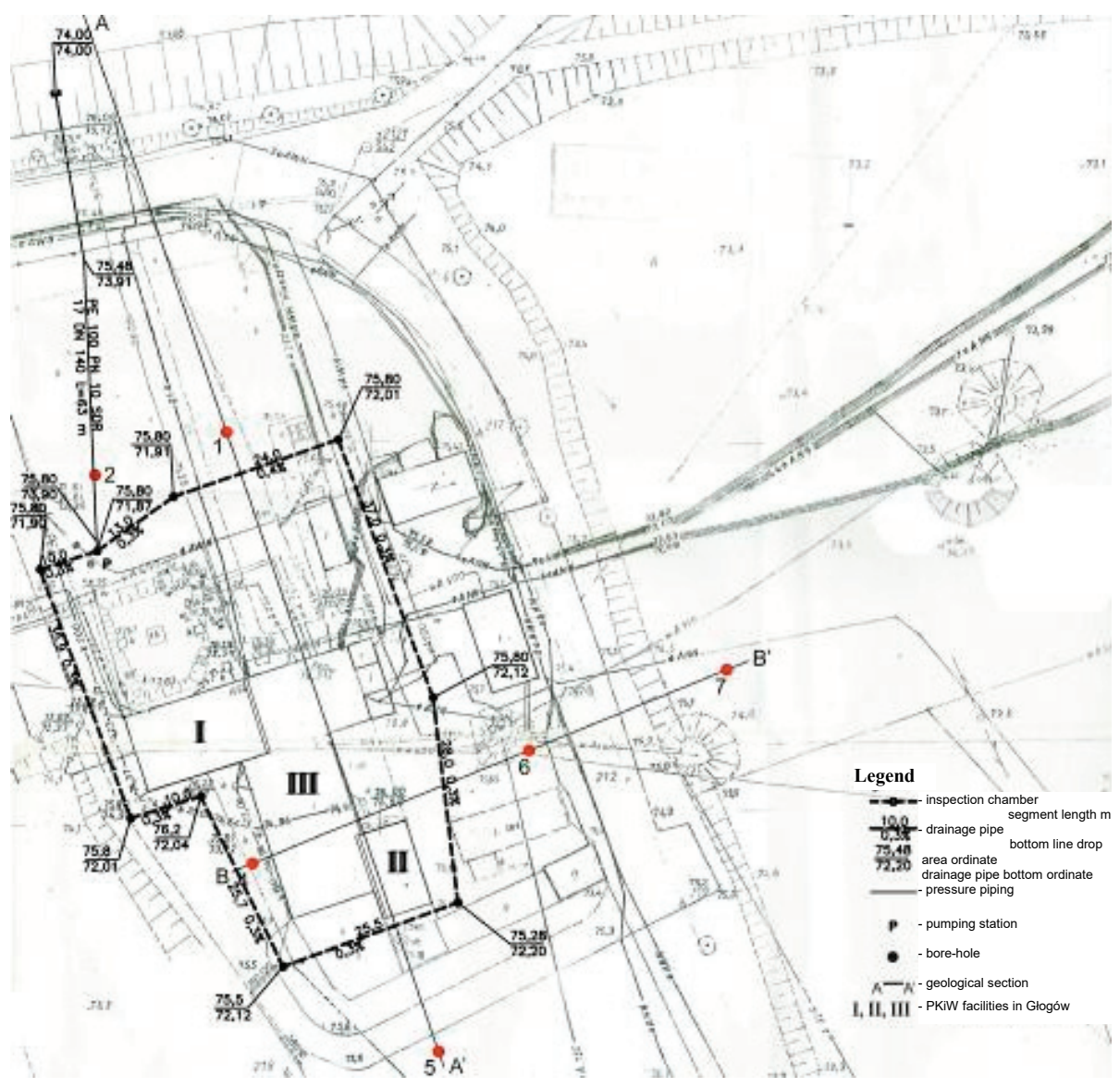

Fig. 5. Draining by means of a non-deepened drainage - variant II 
In this draining variant, engineering solutions similar to those of variant I will be generally applied and any differences will apply to the following conditions:

a) the total length of 160/145 PVC corrugated pipes with $2.5 \times 5.0 \mathrm{~mm}$ holes will be reduced to $209.1 \mathrm{~m}$, with hollows in the pipes $3.08-4.16 \mathrm{~m}$,

b) the time of filling the operating chamber of the drainage water pumping station will be $1.41 \mathrm{~min}$ at the alert level and $2.04 \mathrm{~min}$ at the flood level (as observed in May 2011).

The cost of drainage of the PWiK facilities in Głogów with the use of variant II will amount to ca. PLN 2.8 million.

\subsection{RAISING CELLAR FLOORS COMBINED WITH INNER DRAINAGE - VARIANT III}

In this draining variant, it is planned that the cellars will be filled with grainy material (with graining $\min .2 \mathrm{~mm}$ ) to the height of ca. $1.4 \mathrm{~m}$ above the level of the floor.

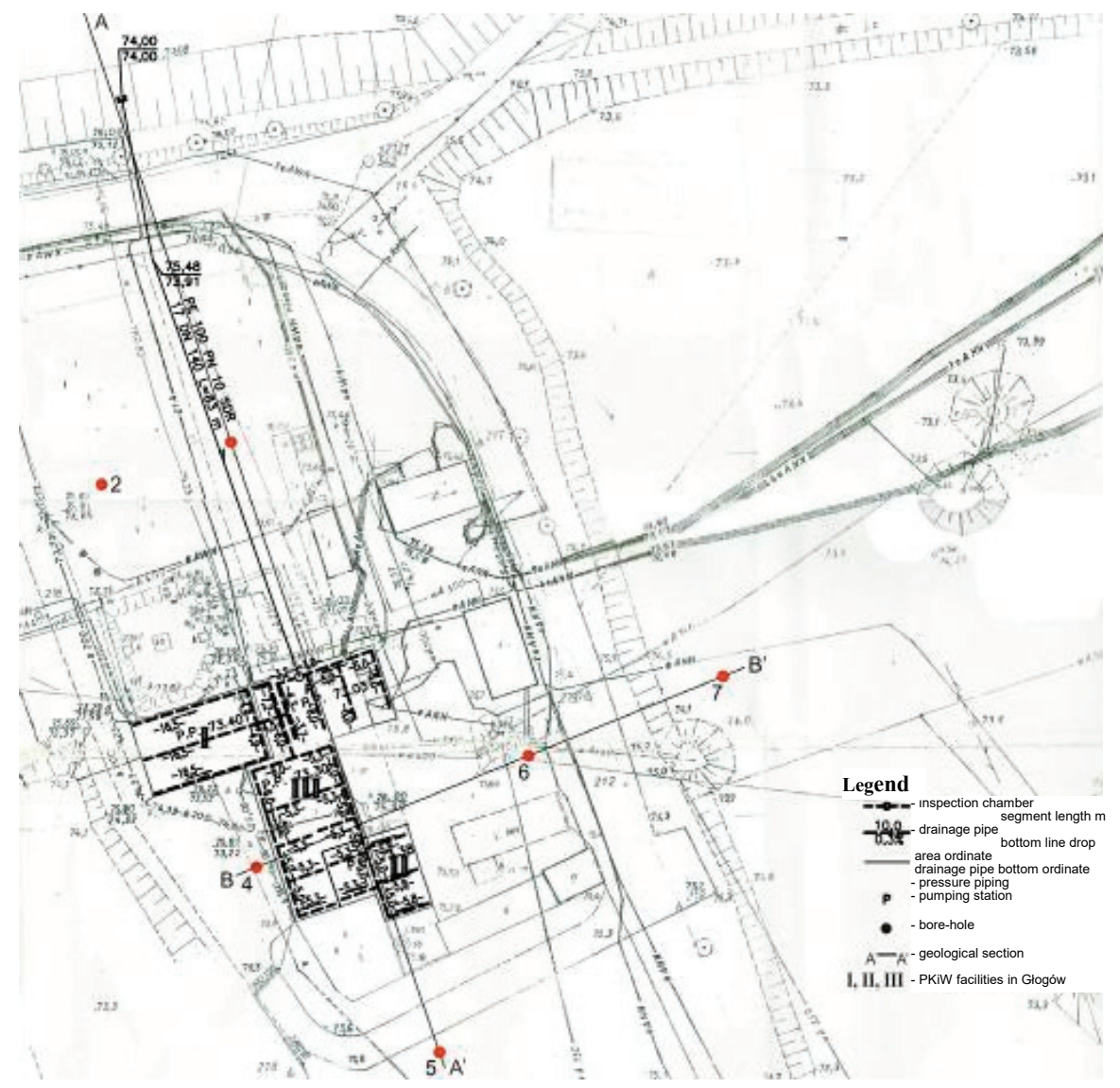

Fig. 6. Draining through raising the cellar floor and performing internal drainage 
However, this is related to putting most of the cellar rooms out of operation; the room height will be then reduced to 2.8 (at present, they are up to $4.2 \mathrm{~m}$ high and are used for storage). Irrespective of further possibilities of using the rooms after the solution implementation, it is recommended that internal drainage in all the rooms is made; drainage with PVC 50/44 pipes with holes $1.5 \times 5.0$, with a total length of $250.0 \mathrm{~m}$ laid on the existing floors is proposed (Fig. 6). The volume of waters inflowing to all rooms - in the event of the occurrence of an alert condition - was estimated in this variant at $12.6-25 \mathrm{~m}^{3} / \mathrm{d}$ and the cost of carrying out the drainage - at ca. PLN 1.6 million.

\subsection{SEALING WITH CHEMICAL AGENTS - VARIANT IV}

Another variant for the drainage of the PWiK facilities in Głogów is sealing cellars with chemical agents (e.g., Botazit BE 901). This applies to all floors and walls of the cellars to the level of $0.3 \mathrm{~m}$ above the ground level, both from the outside and the inside. In this case, it will be possible to maintain the current function of the cellars.

The cost of sealing PWIK facilities in Głogów with chemical agents will amount to ca. PLN 700 thousand.

\section{INDICATION OF THE OPTIMUM DRAINAGE CONCEPTION}

The analysis of the solutions suggested and the results of the calculations made during the development of the draining conception for the PWiK facilities in Głogów led to the following conclusions:

- the non-deepened drainage performed according to variants I and II is related to a significant lowering of the underground water table within ca. $400 \mathrm{~m}$ from the facility. It is connected with an increased inflow of water from the side of the Old Odra and, in consequence - a worsening of the existing ground and water situation and an increased intensity of water inflow to the drainage,

- both variant I and variant II are related to a significant intervention in the existing infrastructure. Both variants require excavations to be made in the existing developed areas used currently as car-parks or access roads,

- in the event of the implementation of variant II, in spite of the slightly lower execution cost compared to variant I, there is a risk of disturbing the ground base stability, which results from too short a distance between the drainage and the building walls,

- a decrease in the range of the area covered by the drainage in variant II in relation to variant I paradoxically has no significant impact on either the depression sink or the volume of the ground water removed as required for reaching the expected result,

- the application of variant III, based, among other things, on internal drainage, allows the unfavourable impact of the capital investment on the area surrounding the 
project to be avoided, but, at the same time, makes it impossible to use the cellar rooms later on (due to their becoming shallower),

- the application of sealing with chemical agents (variant IV), the most advantageous from the point of view of investment cost, may, however, be a source of many problems which are difficult to indicate directly at the current stage of the work,

- all the solutions suggested take into consideration only a general outlay of the cellar division but they do not include all load-bearing walls. Provision of the above preconditioning with details will only be possible at the stage of the construction design, combined with a detailed inventory and foundation exposure.

\section{SUMMARY}

The draining of the cellars of the PWiK facilities in Głogów, at 52, Łąkowa St. is a very complex problem. Resulting from the location of the facilities in a floodplain, the close vicinity of the Old Odra, as well as from the ground and water conditions. Only in recent years, flood waters have entered the cellars of the facility several times and ground waters stay there almost permanently. Therefore, both the floors and walls of the cellars are in a condition of permanent dampness and, frequently - flooding.

As part of the study, the directions and intensity of the water filtration in the foundation of the PWiK buildings in Głogów was analysed and four different methods of counteracting these processes were indicated: variant I - outer drainage, variant II - outer drainage to a smaller extent, variant III - raising the floors of the cellars and internal drainage and variant IV - sealing cellar floors and walls with chemical agents.

It follows from the analysis conducted that none of the specified variants is perfect and none of them guarantees the complete drying of the cellars of the facilities under consideration. At the same time, each of them requires a significant outlay of funds and some of them even resignation from using most of the cellars. Therefore, it seems that the most appropriate solution for PWiK in Głogów is the construction of new facilities, definitely not provided with cellars, where the stores situated at present in the damped cellars could be relocated.

\section{REFERENCES}

Cirkel R.J. (ed.), Poradnik projektanta obwatowań rzecznych, Biblioteka Partnerstwa dla Odry, Wrocław, 2000.

KoŁODZIEJCZYK U., KowALSKI W.C., Engineering - geological investigations on flood banks in river valleys of the east mid-European lowland, Biull. IAEG, 2002.

KoŁODZIEJCZYK U., Inżyniersko-geologiczne badania watów przeciwpowodziowych lubuskiego odcinka Odry, Oficyna Wydawnicza Uniwersytetu Zielonogórskiego, Zielona Góra, 2002.

WróBEL I., Wody podziemne Środkowego Nadodrza i problemy ich ochrony, Wyd. WSI Zielona Góra, s. Monografie 50, 1989. 